\title{
What Future for Policing? Some Reflections on the Concept and Purpose of Policing and Their Implications for Police Reform in England and Wales
}

\author{
Andrew Williams ${ }^{1} \&$ Craig Paterson ${ }^{1}$ \\ ${ }^{1}$ Helena Kennedy Centre for International Justice, Sheffield Hallam University, Sheffield, UK \\ Correspondence: Craig Paterson, Helena Kennedy Centre for International Justice, Sheffield Hallam University, \\ Collegiate Crescent Campus, Sheffield, S10 2BP, UK. E-mail: c.paterson@ shu.ac.uk
}

Received: November 20, 2019

Accepted: December 6, 2019

Online Published: March 20, 2019

doi:10.11114/ijlpa.v2i1.4158

URL: https://doi.org/10.11114/ijlpa.v2i1.4158

\begin{abstract}
Policing develops in different ways at different times and to differing demands in states around the world. Thus, policing and security models are established and evolve in the context of the host society. In England and Wales, modern bureaucratic policing emerged from a locally focused and administered system. Following on from this, contemporary Anglo-American policing aligns, to varying degrees, with the political, socio-cultural, legal and ideological aspects of contemporary liberal democratic society with its emphasis on democratic localism and decentralised accountability. Policing is also a field where Anglo-American and other western states provide support to transitional states with often different developmental paths. The transitional states seek, or have imposed on them (depending upon your perspective), western democratic models of policing and the policies, programmes, institutions and tactics associated with these models. This paper reviews the conceptual and theoretical assumptions that underpin thinking about policing and asks whether there is a sufficiently common philosophical and conceptual understanding of policing across nation states to support the development of policing rather than just a common understanding of police functions. This is profoundly important when considering different conceptual understandings of policing and how that is applied in support of the reform of policing in transitional states. The paper calls for a concerted effort to conceptualise a philosophical understanding of policing and its relationship to social development.
\end{abstract}

Keywords: policing, development, concept, alignment, reform.

\section{Introduction}

Following the 2018 conference of the National Association of Retired Police Officers (NARPO), 180 retired police officers started a petition calling for a royal commission to review policing in England and Wales (Moore, 2018). This was the latest in a series of calls for a review of policing across the United Kingdom that includes, amongst others, DEMOS in 2006, the Guardian in 2013 and the Police Federation in 2017. Alongside this, chief police officers are becoming increasingly vocal in their calls for fundamental changes to the demands made of the police with the Chair of the National Police Chiefs Council's call for reform supported immediately by other chief officers and some police and crime commissioners (BBC, 2018; The Evening Standard, 2018; Hampshire PCC, 2018). In October 2018 Consulting firm Deloitte published a synthesis of their experiences of policing across the United Kingdom (UK) and identified that society has fundamentally changed and policing, in this instance the public police, needs to change to meet evolving social needs. Other countries seem to agree with Canada (Council of Canadian Academies, 2014) and Ireland (Commission on the Future of Policing in Ireland, 2018) undertaking fundamental reviews of policing rather than the tinkering around the edges of police reform (Vitale, 2017).

Arguably, the last fundamental review to consider the needs of British society in determining how it was policed was in the 19th century when modern policing emerged out of demands for a more bureaucratically sophisticated, demilitarised and de-politicised police. It was argued, from different perspectives, that this modern police organisation would meet the expectations of a society experiencing simultaneous mass urbanisation, industrialisation, market liberalisation and political reform. These police reforms acknowledged the diminishing role of small communities who had themselves exerted social management through populist local structures, patriarchal militias, private police organisations and other localised 'police' bodies. The modern policing system in England and Wales matured throughout the next century with periodic reforms emerging in the second half of the twentieth century with the 1960 Royal Commission (Willink, 1960; 
Willink 1962), the 1978 Edmund-Davies's Review, the 1982 Scarman Report and the 1999 MacPherson Report. These reviews focused on the future of policing but through the lens of pay, conditions and governance and latterly concerns with structural bias and discrimination. These reviews and Royal Commissions were thus thematic rather than fundamental.

In the United States, a more radical discourse has emerged which questions whether there is a need for a police at all. Vitale (2017) argues that the current model of policing no longer meets the needs of contemporary society and that it is time to fundamentally review the impact of societal change and its associated modes of governance, arguing in tandem that it is time to end the militarisation and politicisation of policing in New York and the wider US. In this way Vitale's critique of US policing reflects those of late 18th and early 19th century commentators (Fielding, 1757; Colquhoun, 1806) who argued that society was in transition and there was a need to re-imagine policing. This critical reflection paved the way for the development of the London Metropolitan Police and the establishment of the principles of policing by Robert Peel and codified by Rowan and Mayne (Lawson, 1988; Bush, 2005; Poole, 2006). It can be argued that the emergent industrialised modernism that surrounded the police reforms of 1829 and has survived for nearly 200 years requires re-visiting in a time where technology, government and society are radically re-shaping themselves. There is evidence of this reform discourse in England and Wales but, as the opening section acknowledges, it is often grounded in the self-interest of organisations, think tanks and political positioning. Thus, it does not explore the critical question of what policing, as opposed to a narrower definition of police, needs to look like in the future. The title of this paper thus emerges, "What future for policing?"

There are examples of future casting for major and critical national and international issues. The UK Ministry of Defence (2014) undertake a periodic strategic trend review and the latest version, looking forward to 2045, examines futures in social, technological and geographical terms along with the changing nature of state and governance. The purpose is to ensure that structures, technologies, capability and organisation are developed to meet that need. This strategic vision seeks to ensure that people, funding, policies and capabilities are fit for purpose into the future. In the same way as the military seeks to understand what the future of security and defence may look like based on what society, technology, state and threat vectors may be so, in the civil world, we need to understand not only the future but the present. Global societies are in transition both structurally and conceptually. Communities of interest are no longer co-located and communicating face to face; instead, they often communicate virtually, sometimes ethereally and occasionally incognito. Property crime occurs, as do crimes against the individual, in an increasingly electronic world as we move deeper into the age of 'crime sans frontiers'. Telecommunications and written interactions can no longer be assumed to be with a human being somewhere nearby but may be with some artificial intelligence bot across the world.

In such a climate it is surely right for societies and their governments to stop asking how we pay for the police and how many police officers we can afford. Instead, we should ask what is meant by policing and what do modern societies and communities need, want and expect today and into the future. If we examine these issues at a fundamental and philosophical level, the delivery of policing will be driven once again by the needs of society and potentially by a very different discussion and model than that which emerged in the 1820s and 1830s.

\section{Radicalism and Reform in England and Wales}

Policing in England and Wales is undergoing radical shifts. The establishment of Police and Crime Commissioners re-introduced a more political aspect to contemporary policing that had been missing since the advent of professional policing in the nineteenth century. Added to this, a decade's worth of fiscal austerity has fundamentally re-shaped the policing landscape with future vision statements envisaging a service that is leaner and more reliant on technology (NPCC, 2016). Over the same decade, individual and collective vulnerability have become prominent concerns and accelerated the partnership and community-oriented shifts in the foci of policing that had been evident since the re-emergence of community policing as a policing policy goal in the late 1980s.

The subsequent three decades of experimentation with ways to re-connect police organisations with communities, re-build public confidence and police legitimacy, and contribute to reductions in recorded crime through proactive engagement with crime and other social problems led to fundamental changes to the police role and function. Furthermore, this process stretched the remit of policing, without any formal government reviews of the police role, to include partnership responses to social problems, proactive community crime prevention, and the management of public fear. This simultaneous broadening and lengthening of the police role had led to a belated recognition that policing is intimately connected to highly complex social issues such as public health, anti-social behaviour, community cohesion and nation security, to name just a few (Bittner, 1970; Neocleous 2006; Manning, 2010).

Despite this recognition of the enhanced complexity of policing, its manifold models, structures and strategies and their relationship with other aspects of social, political and economic development have remained largely under-theorised and under explored (Brodeur, 2010; Manning, 2010). Developments in other academic disciplines require an 
understanding of first principles, or underlying assumptions, in an area of study before proceeding to additional investigation. Yet, the extent of this reflexive, philosophical thinking is conspicuous in its absence in the context of policing. This absence of reflexivity is most notable in the realm of international policing where different legal, social, cultural and political conceptualisations of policing come together and have direct implications for practice (Hills, 2014). We will discuss this further in the upcoming sections.

The key question for this paper is thus - do those change agents who plan, drive and implement policing reforms, including academics, consultants, pressure groups, think tanks and practitioners, have a comprehensive understanding of first principles in relation to policing which can then be used to ensure proposed changes are sufficiently contextualised in order to optimise the chances of successful and sustainable reform? Given this context, the purpose of this paper is to:

1. Consider the concept of policing in relation to socio-economic, political and technological change;

2. Determine whether existing assumptions about the philosophical nature of policing are sufficient to drive and direct effective police reform;

3. Identify if there is a need to re-consider existing conceptualisations and assumptions about first principles in policing within a context that extends beyond individual nation states

The paper firstly assesses current thinking amongst western academics about the concept of policing before reflecting upon the underpinning assumptions that emerge from this literature. The paper then considers conceptualisations of policing in a variety of historical, transitional and non-western contexts and argues for the identification of a philosophical conceptualisation of policing that can be aligned to societal need to assist in developing strategies and plans for effective and sustainable reform. The paper identifies a gap in this area, thereby setting an agenda for academics and professionals working in this field to consider the philosophical 'first principles' of policing before embarking on reform endeavours.

\section{What is Policing? Interrogating Western Conceptualisations}

Policing scholars recognise the importance of separating the institution and functions of the police from the looser concept of policing and, in twenty-first century debates, this conceptualisation has been stretched further to focus upon 'security' (Johnston and Shearing, 2003; Reiner, 2010). Contemporary explorations of 'security' and 'policing' acknowledge plural networks of social control (Bayley and Shearing, 1996; Ibid., 2003) although with a recognition of the prominent symbolic role of state police (Loader and Mulcahy, 2003; Stenson, 2005). Following on from this, modern, post-enlightenment societies have been characterised by generic assumptions that invoke 'the police' as an essential requirement for the maintenance of order, without which society would be, to some degree or other, reduced to chaos (Hobbes, 1640; Emsley, 1991; Reiner 2010). Yet, as Neocleous has noted (2006: 17), 'most research on the police eschewed any attempt to make sense of the concept itself or to explore the possible diversity of police powers in terms of either their historical origins or political diversity'. Manning (2010) agrees, commenting that this failure to engage with the underlying philosophical assumptions that direct thinking about policing has led this emerging sub-discipline to develop in an atheoretical manner (Manning, 2005). This article seeks to promote engagement in this fundamental issue and to provide a loose conceptual framework for thinking about policing that also has practical implications for those working in the field.

Leaving aside 'policing' and 'security' for a moment, there is undoubtedly a need within all societies for order and the imposition of rules (Durkheim, 1912; Tomlins, 2006; Fukuyama, 2012). For example, Silver (2008) considers order in civil society but only in the context of the demand for, and emergence of, the bureaucratic 'modern police'. Fukuyama's 2012 work, The Origins of Political Order, reviews historic and contemporary biological, sociological and political work to try and understand the pre-historic nature of society and concludes that human kind, cognisant of the perpetual threat of conflict, is disposed towards community and socialisation and that from the earliest human and pre-human periods, rules have been set and transgressors held to account.

This perspective is not new. In the early twentieth century Durkheim (1912) noted that as societies develop, religiously-driven rule-making and enforcement evolve alongside other social and cultural changes. This analysis of the development of rules is closely aligned to the biblical justifications of natural law put forward by Hobbes (1651), Locke (1690) and Rousseau (1762), and to a lesser extent Kant (1797). These societal genesis perspectives are reflective of Durkheim's view that religion is important to the development of societies in supporting the coalescence of social units and class (including leaders) that is required for social cohesion. In a similar vein, Locke argues that proto-societies require the support of individuals and a patriarch to provide judgment on incivilities and other transgressions. Thus, in the earliest human societies, policing existed as an organic function rather than as a formally organised capability. As human kind formed larger social groupings beyond simple kinship, the rules of society were increasingly enforced by 
the community or tribal leaders; individually or in some form of caucus (Durkheim, 1893; 1912). In Europe, the growth of communities and societies meant that by the late fifteenth century the French-Burgundian term policie had emerged. The meaning of this term gives some indication of what policing in that period had become, namely:

The legislative and administrative regulation of internal life of a community to promote general welfare and the condition of good order and the regimenting of social life (Neocleous, 2006 p22).

Contemporary policing scholars have subsequently considered whether there are theoretical and philosophical principles that underpin the concept of policing. Manning (2010) and Neocleous (2006) have concluded that there is no theory of policing with Manning proposing justice as a lens through which to develop a theory of policing. Manning's work asserts that attempts to develop a theory of policing have been unsuccessful because policing studies remains an emergent discipline that observes and reports on the concerns of practitioners, the public, politicians and increasingly, the international community rather than being pre-disposed to criticality. Manning (2016) has reviewed the possibility of developing an anthropology of policing as an alternative vehicle for critical studies and concludes that it is the socio-legal and administrative genesis of policing studies which limits the discipline to reporting and commenting on developments in policing rather than theorising, challenging and testing. Hence, definitions of policing tend to be atheroretical, bound to individual nation states, and problematic when placed in a comparative context.

Similarly, Brodeur makes extensive efforts to develop a theory of policing in his 2010 work, 'The Policing Web', but he fails to adequately describe and articulate a concept of policing. In the lengthy conclusion Brodeur remains unable to disconnect the philosophical concept of policing from the functions, agents and organisations of 'the police'. Brodeur provides a strong case for policing to be understood in a broader context than is currently the case but he fails to deliver a cogent concept of policing on which to develop his theory so that it can be tested empirically.

\section{What is Policing? Moving Beyond Western Conceptualisation}

We argue the absence of a philosophical conceptualisation of policing is profoundly important because foundational texts for police officers or policing students fail to address the fundamental or universal aspects of policing that extend beyond each nation state and instead focus upon the role and function of police organisations (Kapoor, 2015; Paterson and Williams, 2018). We argue that this predisposition to function without concept has had a profound effect on the discourse concerning the transferability and reform of policing models. One simple way of challenging these assumptions is to step outside of mainstream western discourse and to engage with different legal, social, cultural and political perspectives. To illustrate this, we draw on the international policing literature and post-colonial perspectives as they draw insight from different development contexts with varied social needs (for example, Cole, 1999; Kapoor, 2013; Tankebe, 2013).

Ellison and Pino (2012) argue that any policing assistance to overseas states must be set alongside, or as an enabler for economic, social, political and cultural change and must also nurture a democratic process. Policing is thus inseparable from the context it is embedded in. This politically utilitarian approach is reiterated by other western scholars such as Szikinger (2001) and Pino and Wiatrowski (2006) as well as by some state development organisations (Denney and Domingo, 2017). Yet, as Tankebe (2013) and Kapoor (2013) note, in practice there is a misalignment between the intent to build stable democratic institutions with access to justice for all and the functions of post-colonial or post-conflict policing agencies which tend to support the established political order. Herewith, we identify fundamental differences in the conceptualisation of policing that relate to the contemporary social order.

Many contemporary transitional states have a pluralised form of policing based on non-state actors providing a community-centric policing function in the absence of, or as a supplement to, an established centralised policing capability (Grabosky, 2009; Hills, 2014). This structure reflects Fukuyama's (2012) description of pre-modern and tribal societies. Tribal societies in pre-Roman Europe, Asia, Africa, and on the Arabian Peninsula had collective and, often, consensual justice administered by combinations of individuals from the tribe or community and generally agreed to by those members of the community or tribe. In transitional states this remains the extant situation as modes of communal policing continue to exist alongside other modern modes of policing. Cole (1999) and Marenin (2009:353), considering African states, identify and describe a vast informal social ordering system that does what the state police are unable to do. More specifically, Schmeidel and Karokhail (2009:320) describe the arabaki as a community based customary policing structure that focuses on the tribal issues of the Pashtun in Afghanistan. In Benin, Bierschenk and de Sardan (2003, p158) describe the local forms of dispute resolution in the rural tribal communities and identify the diverse forms of legitimacy that exist across communities. Similarly, Braithwate and Gohar (2014) consider legal plurality in tribal areas of Pakistan and identify multiple policing structures with a similar genesis and status to the developing state systems. 
Ignorance of these fundamental differences is most commonplace in the evangelising of western models of policing that takes place during policy transfer to states in transition. Despite widespread evidence that policy implantation does not work (Evans, 2004a; 2004b; 2004c; 2004d; Ivanova, 2004; Jones and Newburn, 2007), this evangelising occurs, in part, due to introspection on the part of government and change agents but also assumptions that effective policing is the replication of extant practice in the donor country. This assumption continues to exist regardless of evidence that highlights an absence of sustained positive impact in the beneficiary country (Hills, 2014) or an appreciation of the political, socio-cultural, ideological or legal context of the beneficiary state (Williams, 2014). The consistent replication of these findings provides a rationale for further investigation and interrogation of the concept of policing, using global and comparative analysis, so that future policing and development reform is aligned to the specific needs of a society.

Hitherto, descriptions of policing have been embedded in the Weberian view that the police exercise authority over the public and are the manifestation of the state's legitimate use of force or coercion (Bittner, 1970: 36-47). Developing this point beyond a focus on the state, Bayley and Shearing (1996: 715-716) describe policing as 'the self-conscious processes whereby societies designate and authorise people to create public safety'. Yet, this perspective can also be contested in contexts where police authority is not necessarily perceived by the public to be legitimate (even if it is a manifestation of state power). Conceptualisations of policing belong to specific times and places and should not solely be defined by the actions and activities of personnel. Thus, Bittner's police use of force paradigm is too narrow, descriptive and state-centred to provide a satisfactory basis for conceptualising the nature of either historic or contemporary modes of policing, particularly in contexts where multiple modes of policing exist ${ }^{\mathrm{i}}$.

So, it is important to recognise the assumptions that underpin the philosophical concept of policing rather than simply providing a description of near-contemporary functions. Continued failure to do this precipitates the observation of policing through the lens of accountability, effectiveness and policing being 'what the police do' (Waddington and Wright, 2010). The consequence of such a position is to reinforce Ellison and Pino's assertions about cultural dislocation and contextual failure and to deliver non-aligned models of policing that will be rejected outside of the specific context of the donor state (Williams 2014).

In Anglo-American policing studies there remain many descriptive definitions of what policing does but very few full attempts to fully conceptualise policing and to identify what it is beyond Bittner's insights from his work in the late 1960s. This represents a challenge for policing studies to extend its lens beyond 'rampant empiricism' (Manning, 2005). The next section of this paper reflects on recent attempts to conceptualise 'police' and 'policing' and to take policing studies beyond its traditional concern with role, function, culture, accountability and effectiveness toward a more holistic appreciation of the conceptual meaning of policing that can inform reform endeavours.

\section{On Concepts}

By a concept of policing, we mean the 'most basic linguistic constructions by means of which people order and categorize reality' (Mouton and Marais, 1988: 58). A concept of policing is therefore our most basic tool for analysing, debating and making sense of our own understanding of policing. It is a symbolic construct which conveys meaning about the purpose of policing, much of which underpins public discourse about what the police do and should do but is largely taken to represent common-sense assumptions which are often specific to context. This conceptual meaning can be defined through reference to the basic dimensions of a concept; its connotation (the meaning of policing as it is conveyed to people) and its denotation (the phenomena which exist in reality when we refer to policing). The connotative dimension refers to theories, perspectives and interpretations of policing whereas the denotative dimension refers to things that can be empirically measured. As an example of this, Hills' (2014) refers to 'policeness' as the fundamental characteristics of police (what we refer to here as first principles) that transcend nation states. In doing so, Hills identifies three terms that commonly characterise connotative and denotative conceptualisations of police and which have relevance to the broader conceptualisation of policing. These terms - coercion, professionalism and discipline - are briefly outlined in the next section.

\subsection{Coercion}

The use of actual or threatened force and intimidation (Hills, 2014: 768). This term draws on Bittner's (1970: 131) interpretation of police as an 'institution with the monopoly to employ non-negotiably coercive force' although Hills extends this definition to include 'the technical skills associated with a specialist coercive knowledge' (2014: 775) and thus other non-state modes of policing. The coercive function of policing is both imagined, in that it does not need to be implemented to have impact, and actual.

\subsection{Professionalism}

The giving of recognition and authority to a body of people to police. In western contexts, professionalism is often identified by the public in the form of a specific uniform although, in governmental terms, professionalism arises from 
training, status and accountability to civil society. From a non-western perspective, and reflecting Durkheim's work on order and change, professional 'policeness' relates to ownership of the knowledge, skills and power required to fulfil societal or political expectations about the management of low-level forms of disorder. Professionalism is thus often deemed to separate formal state police bodies from the myriad of other policing bodies that exist in societies.

\subsection{Discipline}

There is an Anglophone assumption that the term 'police', as opposed to policing, refers to an organised and often hierarchical body of people. Underpinning this perspective is recognition that training, acculturation and hierarchy impose discipline upon police with the threat of punishment where this discipline is breached. Anglophone perspectives on discipline are traditionally predicated on state-centred and rule-oriented models devised in contexts where resources are plentiful for the efficient administration of policing but these assumptions are challenged in states with plural modes of policing and governance where system of governance have evolved in a multitude of different ways. In this latter context, discipline can be understood as a form of governmentality; a technique of governance and an expression of power relations (Foucault, 1991)

Coercion, professionalism and discipline provide a loose framework for understanding some basic characteristics, or first principles, of police and policing which have meaning across a range of contexts. These characteristics comprise elements of the denotative and connotative dimensions of policing that can be applied to reform endeavours and, in some instances, measured in practice. These fundamental characteristics of policing gather local meaning in their specific socio-cultural, legal, ideological and political contexts. Coercion is an ever-present element of policing although the extent of professionalism and discipline in policing organisations undoubtedly differs and changes across time and space. For example, public responses to state, voluntary and commercial modes of policing differ dramatically across national jurisdictions, geographical locations and at different points in history (Bayley and Shearing, 1996; 2001). The meaning of policing is therefore constructed both at the state level through law, policy and varying levels of professionalism but also at the local level where micro-politics, social norms and culture inform the ways in which coercion and discipline are perpetually negotiated and managed.

The challenge presented by this expansive conceptualisation lies within the abstraction that occurs whenever we attempt to generalise to such a degree that the concept in question is unable to identify with the obvious and familiar traits found in any society (Schultz 1954: 266). Policing provides an excellent example of this with each nation state's police organisations being identified by its citizens in terms of its presentation (uniform, structure, societal presence) and its activities. Thus, any conceptualisation of policing in its connotative sense often finds itself marginalised as it has to incorporate how people make sense of a range of policing activities i.e. how people think policing should be done. The consequences of this thinking are evident across Anglophone policing studies which are laden with a multitude of context-specific descriptive definitions of what the police do in democratic societies. This may explain the cyclical nature of police reforms as ideas about what policing is or should be are recycled and repackaged in new forms with old shapes and hegemonic assumptions. As Clamp and Paterson (2016) have acknowledged, there is a need to both broaden and lengthen the conceptual lens through which police and policing are understood. The next section picks up this challenge and uses these insights to generate a conceptual framework that helps align police reforms with its specific context in England and Wales.

\section{Concepts, Police Reform and Social Change}

Analysis of policing through the lens of function rather than concept leads to a failure to question the fundamental assumptions that underpin thinking about policing and police reform projects. A concept of policing that has application beyond nation states needs to draw on a broader range of analytical and theoretical tools than descriptive definitions of the police role and function. Manning (2010) draws upon Rawls's theory of justice, Foucault extracts meaning from the dispersal of disciplinary power and Hills (2014) utilises Durkheimian insights into the sociological meaning of policing. Together, as Bittner (1970) did before them, they identify coercion and discipline as the fundamental characteristics of policing with professionalism and the pursuit of justice as ideological or aspirational goals. While coercion and discipline are fundamental elements of policing, professionalism and justice are variables that shift across time and space to influence the shape of policing structures and organisations in each society.

A minimalist conceptualisation of policing, such as that provided by Bittner (1970) and Brodeur (2010), focuses primarily upon the unique authority and capacity of the police whereas a maximalist conceptualisation of policing, such as that found in the work of Bayley and Shearing (1996;2001), draws upon a broader range of social control processes. The police are often representatives of formal legal systems and this provides them with the authority to resolve conflict and restore order in a variety of ways. Despite this, there are many other statutory, civil and informal bodies that also perform policing functions and that contribute to order through a disparate range of social processes (Porter, 2016). The scope and remit of the police thus differs across societies and renders it difficult to explain the activities of police in 
isolation from other modes of policing. A holistic conceptualisation of policing thus requires an appreciation of legal, political, ideological and socio-cultural contexts to capture both connotative and denotative elements.

A concept is given further meaning when it is employed as part of a theoretical approach. Policing is, in Foucaldian (1991: 87-104) terms, a form of governmentality; that is, a technique of governance and an expression of power relations. As Hills acknowledges (2014: 773), policing is given meaning within specific power structures and, paraphrasing Foucault (1969), 'systems of thought and practice are governed by rules defining the conceptual possibilities determining the boundaries of thought in any given domain or period'. Policing is thus an ideological and cultural construction in that police and policing agencies respond, at least partly, to expectations set for them by political offices, civil and institutional bodies, media, policing cultures, active citizens and other prevailing influences in a society.

Policing is a function of society and a cultural phenomenon driven by the prevailing socio-cultural, ideological, legal and political situation. This was acknowledged, but not fully addressed, by Brodeur (2010) in his attempts to both identify the activities of policing and the importance of the translation of policing purpose in each context. It is important to understand both the legal and socio-cultural conditions in which policing occurs as well as the underlying political and ideological context that shape different forms of policing. Policing is a fundamental part of the social contract agreed to by authorities and citizens when there is a need to ensure that the rules of society are observed and that the leader, or other socially acceptable body, is able to pass judgement on transgressors (Hobbes, 1640; Locke, 1823; Pufendorf, 1991; Kant, 2002). Policing is thus an expression of power that is given shape and form in each social context.

The linguistic challenge of conceptualising policing is evident in the vast array of qualifying terms that are used in the context of policing policy transfer to transitional states: Non State Policing (Baker, 2009a); Peacebuilding and Police Reform (Tanke-Holm and Barth-Eide, 2000); Community Policing and Peacebuilding (Grabosky, 2009); UN Policing (Harrington, 2008); Post-Colonial Policing (Cole, 1999); Private Policing (Johnston, 2000); Post Conflict Policing (Baker, 2009b; 2009b; 2010); Terrorism Policing (Gregory, 2007; Deflem, 2010); Intelligent Policing (Harfield, 2008) and Democratic Policing (Manning, 2010; Pino and Wiatrowski, 2006). Some of these terms describe a new or adapted function; others describe the entity that delivers a function that the author considers to be traditionally or regularly undertaken by the police, while democratic policing describes not just a function or agent but also a value system. Hence, when Szikinger (2001) contends that democratic policing is inseparable from democratic society it is possible to lengthen this lens to argue that policing is seemingly inseparable from existing systems of power in any given context.

The area where there is the greatest need for a clear philosophical conceptualisation of policing and its alignment to social conditions and development is police reform. Security sector reforms (SSR), including policing, have had limited success to date and Chanaa argues that this is because they are a collection of 'undifferentiated and ill-defined strategies' (2002, p.10) that are often missing political or societal support (2002, p.75) due to non-alignment to beneficiary states. Hills (2014: 284) takes this argument further and questions the assumptions that underpin police and governmental thinking in donor countries, referring to UK international policing operations as characterised by "unrealistic assumptions and strategic incoherence".

In her concerns over policing operations in post conflict transitions, Mani (2000) identifies the vagueness of policing concepts as an inhibitor to the development of police doctrines. This has been reported in a number of other works in post-conflict (Hartz, 2000; Harrington, 2006; Harrington, 2008; Hills, 2009; Albrecht and Buur, 2010; Hoogenboom, 2010) and post-colonial (Cole, 1999; Kapoor, 2013; Tankebe, 2013) transitions. Police reforms face a challenge in meeting both the political imperative of the state and the needs of the citizenry that often leads to partly realised ideals and practice. The same argument can be applied to police reform within England and Wales.

\section{Conclusion}

We have argued in this paper that there are a myriad of complexities within policing that evolve as society transforms and, therefore, it is fundamental to scholarly discourse and the development of the police to return to first principles. Policing, in its abstract conceptual sense, can be identified and understood as any empirically measurable (denotative) or symbolic and imagined (connotative) disciplinary processes that seek to maintain and, where appropriate, enforce social rules, values and customs. Police work is underpinned by presumptive compliance (Brodeur, 2010) that only functions once social order has been achieved whereas policing is a preternatural and eternal disciplinary process which adapts according to conflicts over ideology, resources, territory and the right to exercise power. This means any conceptual analysis of policing must be dynamic and attuned to local context and their associated hegemonic expressions of power. Similarly, fundamental police reform needs to be aligned to the needs of the social body and its ever-evolving disciplinary and ordering processes. 
A failure to identify and agree on an underpinning philosophical conceptualisation of policing as distinct from the state-oriented functions of the police undermines attempts to deliver meaningful reform and to align the needs of states and their citizens. Academics and practitioners alike would benefit from an agreed conceptual modelling of policing for the purposes of strengthening debate about police reform in the contemporary world and future policy and practice. This paper seeks to contribute to that discussion. We have identified key elements that underpin conceptualisations of policing or 'policeness' and a need to align this with the legal, political, socio-cultural and ideological development of societies. Providing a cogent understanding of policing, its genesis, development and relationship to society in optimal and sub-optimal circumstances will allow change agents and others to develop coherent pathways for effective and sustainable change.

\section{References}

Albrecht, P.A. and Buur, L. (2010). An Uneasy Marriage: non-state actors and police reform, Policing and Society, 19(4), 390-405. https://doi.org/10.1080/10439460903375182

Baker, B. (2009a). Security in post-conflict Africa: the role of non-state policing. Boca Raton, FL: CRC Press. https://doi.org/10.1201/9781420091946

Baker, B. (2009b). Policing Post-Conflict Societies: Helping Out the State. Policing and Society, 19(4), 329-332. https://doi.org/10.1080/10439460903375158

Bayley, D.H. and Shearing, C. (1996). The future of policing. Law and Society Review, 30(3), 586-606. https://doi.org/10.2307/3054129

Bayley, D.H., \& Shearing, C. (2001). The New Structure of Policing: Description, Conceptualization and Research Agenda. Washington, DC: National Institute of Justice.

BBC (2018). Core policing is under tremendous pressure. BBC News. Retrieved from https://www.bbc.co.uk/news/av/uk-politics-46066106/core-policing-is-under-tremendous-pressure-police-chief

Bierschenk, T., \& de Sardan, J. (2003). Powers in the Village: Rural Benin between democratisation and decentralisation. Africa, 73(1), 145-173. https://doi.org/10.3366/afr.2003.73.2.145

Bittner, E. (1970). The Functions of the Police in Modern Society. Maryland: National Institute of Mental Health.

Braithwate, J., \& Gohar, A. (2014). Restorative Justice, Policing and Insurgency: learning from Pakistan. Law and Society Review, 48(3), 531-561. https://doi.org/10.1111/lasr.12091

Brodeur, J.P. (2010). The Policing Web. New York, NY: Oxford University Press. https://doi.org/10.1093/acprof:oso/9780199740598.001.0001

Bush, M. (2005). The Casualties of Peterloo. Lancaster, UK: Carnegie Publishing

Chanaa, J. (2002). Security Sector Reform: issues, challenges and prospects: Adelphi Papers 344, International Institute for Strategic Studies, Oxford, UK: Oxford University Press

Clamp, K., \& Paterson, C. (2016). Restorative Policing: Concepts, Theory and Practice. London, UK: Routledge. https://doi.org/10.4324/9781315660837

Cole, B. (1999). Post-Colonial systems. In R. Mawby (Ed.), Policing across the world: Issues for the 21st century (pp.88-108). London, UK: Routledge

Colquhoun, P. (1806). A Treatise on the Police of the Metropolis, London, UK: Bye \& Law. Retrieved from: https://archive.org/details/atreatiseonpoli01 colqgoog/page/n7

Commission on the Future of Policing in Ireland (2018). The Future of Policing in Ireland. Report of the Commission on the Future of Policing in Ireland. Dublin, Ireland. Retrieved from http://policereform.ie/en/POLREF/Pages/PB18000006

Council of Canadian Academies (2014). Policing Canada in the 21st Century. Ottawa, Canada: Council of Canadian Academies.

Deloitte (2018). Policing 4.0 deciding the future of policing in the UK. London, UK: Deloitte.

Deflem, M. (2010). The Policing of Terrorism: organisational and global perspectives. New York, NY: Routledge. https://doi.org/10.4324/9780203860380

Denney, L., \& Domingo, P. (2017). Political Economy Analysis: Guidance for legal technical assistance. London, UK: ROLE UK. 
Durkheim, E. (1893:1984). The Division of Labour. Basingstoke, UK: Palgrave MacMillan. https://doi.org/10.1057/9781137284808

Durkheim, E. (1912: 2001). The Elementary Forms of Religious Life (translated from German by Carol Cosman). Oxford, UK: Oxford University Press.

Editorial (2013). Policing: A Royal Commission, now. The Guardian. Retrieved from https://www.theguardian.com/commentisfree/2013/oct/23/policing-a-royal-commission-now

Edmund-Davies, P. (1978). Report of the Committee of Inquiry on the Police. Cmnd 7283. London, UK: UK Parliament.

Ellison, G., \& Pino, N. (2012). Globalization, Police Reform and Development: doing it the western way? Basingstoke, UK: Palgrave Macmillan.

Emsley, C. (1991). The English Police: A Political and Social History. London, UK: Harvester Wheatsheaf.

Evans, M. (2004a). Is Policy Transfer Rational Policy Making. In M. Evans (Ed.), Policy Transfer in a Global Perspective (pp.1-8). Aldershot UK: Ashgate Publishing.

Evans, M. (2004b). Understanding Policy Transfer. In M. Evans (Ed.), Policy Transfer in a Global Perspective (pp.10-41). Aldershot UK: Ashgate Publishing.

Evans, M. (2004c). Policy transfer in a competition state, In M. Evans (Ed.), Policy Transfer in a Global Perspective (pp.64-77). Aldershot, UK: Ashgate Publishing.

Evans, M. (2004d). In conclusion - Policy Transfer in a Global Perspective. In M. Evans (Ed.), Policy Transfer in a Global Perspective (pp.211-226). Aldershot, UK: Ashgate Publishing.

Fielding, H. (1757). An enquiry into the Causes of the Late Increase of Robbers: with some proposals for remedying this growing evil. 2nd edition London, UK: A Miller

Foucault, M. (1969). The Archaeology of Knowledge (Translated by A. M. Sheridan Smith). New York, NY. Pantheon.

Foucault, M. (1991). Governmentality. In G. Burchell, C. Gordon \& P. Miller (Eds) The Foucault Effect: Studies in Governmentality (pp.87-104). Chicago, IL: University of Chicago Press.

Fukuyama, F. (2012). The Origins of Political Order: from pre-human times to the French Revolution. London, UK: Profile Books.

Grabosky, P. (2009). Community Policing and Peacekeeping. Boca Raton, FL: CRC Press. https://doi.org/10.1201/9781420099751

Gregory, F. (2007). Police and Counter Terrorism in the UK: A study of one of the highest most challenging priorities for police forces nationally. In P. Wilkinson, (Ed.), Homeland Security in the UK: Future preparedness for terrorist attack since 9/11 (pp.203-247). Abingdon, UK: Routledge.

Hampshire Police and Crime Commissioner (2018 November 2). Supporting policing, doing what policing and only policing can do to keep our communities safer [Blog post]. Retrieved from https://www.hampshire-pcc.gov.uk/commissioner/my-blog/2-november-2018-commissioner-supports-policing

Harfield, C. (2008). Introduction: Intelligent Policing. In C. Harfield, A. MacVean, J.G.D. Grieve, \& D. Philips, (Eds.), The Handbook of Intelligent Policing: Consilience, Crime Control, and Community Safety (pp.1-8). Oxford, UK: Oxford University Press.

Harrington, A.R. (2006). A Tale of Three Nations? The role of United Nations peacekeepers and missions on the concept of nation-state, nationalism, and ownership of the state in Lebanon, the Democratic Republic of the Congo, Kosovo. Connecticut Journal of International Law, 21(2), 1-38

Harrington, A.R. (2008). Policing the state: United Nations policing as violative of sovereignty, International Law Journal, 10(1), 155-192

Hartz, H. (2000). CIVPOL: The UN instrument for police reform. In T. Tanke-Holm \& E. Barth-Eide (Eds), Peacebuilding and police reform (pp.27-42). Abingdon, UK: Frank Cass.

Hills, A. (2009). Policing Post-Conflict Cities, London, UK: Zed Books Ltd

Hills, A. (2014). What is Policeness? On being police in Somalia. British Journal of Criminology, 54(5), 765-783. https://doi.org/10.1093/bjc/azu049

Hobbes, T. (1640). The Elements of Law. In J.C.A. Gaskin (Ed.), The Elements of Law, Natural and Politic, (1990). Oxford, UK: Oxford University Press. 
Hobbes, T. (1651). On the Citizen. Translation (1998) by R. Tuck \& M. Silverthorne (Eds). Cambridge, UK: Cambridge University Press.

Hoogenboom, B. (2010). The Governance of Policing and Security: ironies, myths and paradoxes. Basingstoke, UK: Palgrave MacMillan. https://doi.org/10.1057/9780230281233

Ivanova, V. (2004). Policy Transfer in a transition state: the case of local government reform. In M. Evans (Ed.), Policy Transfer in a Global Perspective (pp.95-109). Aldershot, UK: Ashgate Publishing.

Johnston, L. (2000). Policing Britain: Risk, security and governance. London, UK: Pearson Education

Johnston, L., \& Shearing, C. (2003). Governing Security: Explorations in Policing and Justice. London, UK: Routledge.

Jones, T., \& Newburn, T. (2007). Policy Transfer and criminal justice: Exploring US influence over British crime control policy. Milton Keynes, UK: Open University Press

Kant, E. (1797). Metaphysics of Morals: Interpretive Essays. (2002) M. Timmons, ed. Oxford UK: Oxford, University Press

Kapoor, V. (2013). Access to justice as the pariah of the development rhetoric: Critical evaluation of governance and policing through the human-rights based approach to development. Paper presented at the 5TH Annual Conference of the Asian Criminological Society. Tata Institute for the Social Sciences, Mumbai, India 14-16 April.

Kapoor, V. (2015). Education for Emancipation and Law Enforcement: Critical pedagogical examination of the human rights education of the police. Paper presented at the CESI conference. Azim Premji University, Bangalore, India 14-16 December.

Lawson, P. (1988). Reassessing Peterloo. History Today, 38(3), 24-29

Loader, I., \& Mulcahy, A. (2003). Policing and the Condition of England: Memory, Politics and Culture. Oxford, UK: Clarendon. https://doi.org/10.1093/acprof:oso/9780198299066.001.0001

Locke, J. (1823). The works of John Locke Volume V: The Second Treatise. London, UK: T. Tegg, W. Sharpe and Sons.

Locke, J. (1988/1690). Two Treatises of Government. Peter Laslett, (Ed.). Cambridge, UK: Cambridge University Press

MacPherson, W. (1999). The Stephen Lawrence Inquiry. Cm 4262. London, UK: UK Parliament.

Mani, R. (2000). Contextualising Police Reform: security, the rule of law and post-conflict Mani peacebuilding. In T. Tanke-Holm \& E. Barth-Eide (Eds.) Peacebuilding and police reform (pp.9-26). Abingdon, UK: Frank Cass

Manning, P. (2005). The Study of Policing. Police Quarterly, 8(23), 23-43. https://doi.org/10.1177/1098611104267325

Manning, P. (2010). Democratic Policing in a Changing World, Boulder, CO: Paradigm Publishing

Manning, P. (2016). Reflections. Theoretical Criminology, 20(4), 502-506. https://doi.org/10.1177/1362480616659818

Marenin, O. (2009). The Futures of Policing African States. Police Practice and Research, 10(4), 349-363. https://doi.org/10.1080/15614260903254999

Ministry of Defence (2014). Strategic Trends Programme: Global Strategic Trends, Fifth Edition: Out to 2045, London, UK: UK Ministry of Defence.

Moore, K. (2018). Protect and Improve Policing in the UK: Hold a Royal Commission. Change. Retrieved from https://www.change.org/p/sajid-javid-protect-and-improve-policing-in-the-uk-hold-a-royal-commission

Mouton, J., \& Marais, H. C. (1988). Basic Concepts in the Methodology of the Social Sciences. Pretoria, South Africa: Human Sciences Research Council.

National Police Chiefs Council (2016). Policing Vision 2025. Retrieved from https://www.npcc.police.uk/documents/Policing\%20Vision.pdf

Neocleous, M. (2006). Theoretical Foundations of the New Police Science. In M. Dubber \& M. Valverde (Eds.), The New Police Science (pp.17-41). Stanford, CT: Stanford University Press.

Paterson, C. \& Williams, A. (2018) Towards victim-oriented police: Some reflections on the concept and purpose of policing and their implications for victim-oriented police reform. Journal of Victimology and Victim Justice. 1(1): 85-101. https://doi.org/10.1177/2516606918764997

Pino, N., \& Wiatrowski, M.D. (2006). The Principles of Democratic policing Democratic Policing. In N. Pino, \& M.D. Wiatrowski (Eds). Democratic Policing in Transitional and Developing Countries (pp.69-98). Farnham, UK: Ashgate. 
Police Federation (2017). Time for a full review into policing. Police Federation. Retrieved from http://www.polfed.org/newsroom/4218.aspx

Poole, R. (2006). By the Law or the Sword: Peterloo Revisited. History, 91(302), 254-276. https://doi.org/10.1111/j.1468-229X.2006.00366.x

Porter, A. (2016). Decolonizing policing: Indigenous patrols, counter-policing and safety. Theoretical Criminology, 20(4), 548-565. https://doi.org/10.1177/1362480615625763

Pufendorf, S. (1991). On the Duty of Man and Citizen According to Natural Law, M. Silverthorne (trans.), J. Tully (ed.), New York, NY: Cambridge University Press.

Reiner, R (2010). New Theories of Policing: a social democratic critique. In D. Downes, D. Hobbs and T. Newburn (Eds). The Eternal Recurrence of Crime and Control: Essays in Honour of Paul Rock (pp. 141-182). Oxford, UK: Oxford University Press. https://doi.org/10.1093/acprof:oso/9780199580231.003.0008

Rousseau, J-J. (1994). The Social Contract [1762]: A New Translation, Christopher Betts. Oxford UK: Oxford, University Press

Scarman, G. (1982). The Scarman Report: The Brixton Disorders 10-12 April 1981. London, UK: Pelican.

Schmeidel, S., \& Karokhail, M. (2009). The Role of Non-State Actors in 'Community- Based Policing' - An exploration of the Arabakai (Tribal Police) in South-Eastern Afghanistan. Contemporary Security Policy, 30(2), 318-342. https://doi.org/10.1080/13523260903060193

Silver, A. (2008). The Demand for Order in Civil Society. In T. Newburn (Ed). Policing: Key Readings (pp.7-24). Cullompton, UK: Willan Publishing.

Stenson, K. (2005). Sovereignty, Biopolitics and the Local Government of Crime in Britain. Theoretical Criminology, 9(3), 265-287. https://doi.org/10.1177/1362480605054811

Szikinger, I. (2001). The Question of Transition. In A. Kadar (Ed). Police in Transition (pp.15-18) Budapest, Hungary: Central European University Press.

Tankebe, J. (2013). In Search of Moral Recognition? Policing and eudaemonic legitimacy in Ghana. Law and Social Inquiry, 38(3), 576-597. https://doi.org/10.1111//si.12025

Tobin, O. (2018). Met chief Cressida Dick backs senior police officer Sara Thornton on tackling burglars and violence ahead of hate crime. Evening Standard. Retrieved from https://www.standard.co.uk/news/crime/met-police-chief-cressida-dick-backs-top-cop-sara-thornton-on-tackling-b urglars-and-violence-not-a3978526.html

Vitale, A. (2017). The End of Policing. New York, NY: Verso.

Waddington, P.A.J., \& Wright, M. (2010). What is Policing? Exeter, UK: Learning Matters.

Williams, A.D. (2014). Policing and Society in the post 2001 Era: model development and the transferability of western models to Arab Islamic States (Unpublished doctoral dissertation). University of Cumbria, Lancaster, UK.

Willink, H, (1960). Interim Report of the Royal Commission on the Police. Cmnd 1222. London, UK: UK Parliament.

Willink, H. (1962). Final Report of the Royal Commission on the Police. Cmnd 1728. London, UK: UK Parliament.

\section{Copyrights}

Copyright for this article is retained by the author(s), with first publication rights granted to the journal.

This is an open-access article distributed under the terms and conditions of the Creative Commons Attribution License which permits unrestricted use, distribution, and reproduction in any medium, provided the original work is properly cited.

\footnotetext{
i Bittner acknowledged this limitation in his conversations with Brodeur about conceptualisations of policing (2010: 103)
} 